\title{
Recent advances in the biology of the Neotropical freshwater crab family Pseudothelphusidae (Crustacea, Decapoda, Brachyura)
}

\author{
Gilberto Rodríguez ${ }^{1} \&$ Célio Magalhães ${ }^{2}$ \\ ${ }^{1}$ Centro de Ecología, Instituto Venezolano de Investigaciones Científicas, Caracas, Venezuela. (In memoriam) \\ ${ }^{2}$ Author for correspondence. Instituto Nacional de Pesquisas do Amazônia, Caixa postal 478, 69011-970 Manaus, \\ Amazonas, Brasil. Research fellow of the CNPq. E-mail: celiomag@inpa.gov.br
}

\begin{abstract}
Pseudothelphusidae is a well diversified group of Neotropical freshwater crabs currently comprising 40 genera and at least 255 species and subspecies. The biology of these crabs has been an active field of research in the last 20 years. The aim of the present contribution is to discuss the significance of the new knowledge on the biology of these freshwater crabs after September 1992, to stress the interconnection of the diverse lines of research and at the same time to suggest promising new lines of investigation. All taxa described from September 1992 to October 2004 are listed, including one genus, one subgenus, 62 species and five subspecies. The implications of this new knowledge on the taxonomy, systematic and biogeography of the family are commented.
\end{abstract}

KEY WORDS. Biodiversity, biogeography, Neotropical region, taxonomy.

\begin{abstract}
RESUMO. Avanços recentes no estudo da biologia dos caranguejos de água doce neotropicais da família Pseudothelphusidae (Crustacea, Decapoda, Brachyura). Pseudothelphusidae é um grupo bem diversificado de caranguejos de água doce neotropicais que compreende atualmente 40 gêneros e pelo menos 255 espécies e subespécies. A biologia desses caranguejos vem sendo um ativo campo de pesquisa nos últimos 20 anos. $\mathrm{O}$ objetivo desta contribuição é discutir o significado do conhecimento adquirido sobre a biologia desses caranguejos dulcícolas após setembro de 1992, enfatizar a relação das diversas linhas de pesquisa e, ao mesmo tempo, sugerir novas linhas promissoras de investigação. São relacionados todos os táxons descritos de setembro de 1992 a outubro de 2004, compreendendo um gênero, um subgênero, 62 espécies e cinco subespécies. São comentadas as implicações desse novo conhecimento na taxonomia, sistemática e biogeografia da família.
\end{abstract}

PALAVRAS CHAVE. Biodiversidade, biogeografia, região Neotropical, taxonomia.

The pseudothelphusids are a group of freshwater crabs of significance in several fields of biology, and in particular in tropical medicine due to the role of many of its species as secondary hosts for several species of lung flukes of the genus Paragonimus Braun, 1899 (Trematoda, Troglotrematidae). These crabs are a food staple in many rural communities in the Neotropics, particularly in Indian communities, passing the helminths not only to man, but also to pigs, dogs, felids and mustelids. From these organisms they pass to the primary hosts that are snails of several genera, to complete their cycles in the crabs (АсHA \& SZYFRES 2001).

The biology of these crabs has been an active field of research in the last 20 years, including their taxonomy, biogeography and phylogenetic. The monograph by RodríGuez (1982) on the family Pseudothelphusidae listed all taxa published to that date, together with the respective bibliographic references. Later this list and bibliography was updated to 1992 by the same author (RoDRíguez 1992). The aim of the present contribution is to discuss the significance of the new knowledge on the biology of these freshwater crabs after September 1992, to stress the interconnection of the diverse lines of research and at the same time to suggest promising new lines of investigation.

New taxa, faunistic lists and taxonomic modifications described after September 1992

Since September 1992, 62 new species and five new subspecies have been described, and one genus and one subgenus have been erected (Tab. I). A review of the literature about the family showed that it currently has 40 genera and at least 255 valid species and subspecies, of which the largest number is found in Colombia (Tab. II).

Mexico. The Mexican species have been dealt with in a series of contributions by Álvarez \& Villalobos (1994, 1996, 1997, 1998) and Villalobos \& Álvarez (2003). Two new species of the genus Phrygiopilus Smalley, 1970, three new Odontothelphusa Rodríguez, 1982, one new Potamocarcinus H. Milne-Edwards, 
Table I. New taxa of the Neotropical freshwater crab family Pseudothelphusidae described after September 1992, with their respective authority and countries of occurrence.

\begin{tabular}{|c|c|c|}
\hline Taxon & Authority & Country \\
\hline \multicolumn{3}{|l|}{ Epilobocerinae } \\
\hline Epilobocera & Stimpson, 1860 & \\
\hline E. capolongoi & Pretzmann, $2000^{1}$ & Cuba \\
\hline E. cubensis cubensis Natio baracoensis & Capolongo \& pretzmann, 2002 & Cuba \\
\hline E. cubensis cubensis Natio guisensis & Capolongo \& pretzmann, 2002 & Cuba \\
\hline E. cubensis najasensis & Capolongo \& pretzmann, 2002 & Cuba \\
\hline E. gilmani cuevanensis, nomen nudum & Capolongo \& Pretzmann, 2002 & Cuba \\
\hline E. gilmani placensis & Capolongo \& Pretzmann, 2002 & Cuba \\
\hline E. gilmani synoecia & Capolongo \& Pretzmann, 2002 & Cuba \\
\hline E. wetherbeei & Rodríguez \& Williams, 1995 & Hispaniola \\
\hline E. (Neoepilobocera) type: E. (N.) gertraudae Pretzmann, 1965 & Capolongo \& Pretzmann, 2002 & Cuba $^{2}$ \\
\hline \multicolumn{3}{|l|}{ Pseudothelphusinae: Hypolobocerini } \\
\hline Chaceus & Pretzmann, 1965 & \\
\hline C. curumanensis & Campos \& Valencia, 2004 & Colombia \\
\hline C. ibiricensis & Campos \& Valencia, 2004 & Colombia \\
\hline Hypolobocera & Ortmann, 1897 & \\
\hline H. barbacensis & Campos, Magalhães \& Rodríguez, 2002 & Colombia \\
\hline H. bouvieri rotundilobata ${ }^{3}$ & Rodríguez, 1994 & Colombia \\
\hline H. dantae & Rodríguez \& Suárez, 2004 & Peru \\
\hline H. emberarum & Campos \& Rodríguez, 1995 & Colombia \\
\hline H. esmeraldensis & Rodríguez \& Sternberg, 1998 & Ecuador \\
\hline H. kamsarum & Campos \& Rodríguez, 1995 & Colombia \\
\hline H. konstanzae & Rodríguez \& Sternberg, 1998 & Ecuador \\
\hline H. mindonensis & Rodríguez \& Sternberg, 1998 & Ecuador \\
\hline H. muisnensis & Rodríguez \& Sternberg, 1998 & Ecuador \\
\hline H. murindensis & Campos 2003a & Colombia \\
\hline H. noanamensis & Rodríguez Campos \& López, 2002 & Colombia \\
\hline H. ucayalensis & Rodríguez \& Suárez, 2004 & Peru \\
\hline H. velezi & Campos, 2003a & Colombia \\
\hline Lindacatalina & Pretzmann, 1977 & \\
\hline L. sinuensis & Rodríguez, Campos \& López, 2002 & Colombia \\
\hline L. sumacensis & Rodríguez \& Sternberg, $1998^{4}$ & Ecuador \\
\hline Moritschus & Pretzmann, 1965 & \\
\hline M. altaquerensis & Rodríguez, Campos \& López, 2002 & Colombia \\
\hline M. caucasensis & Campos, Magalhães \& Rodríguez, 2002 & Colombia \\
\hline Neostrengeria & Pretzmann, 1965 & \\
\hline N. aspera & Campos, 1992 & Colombia \\
\hline N. binderi & Campos, 2000 & Colombia \\
\hline N. gilberti & Campos, 1992 & Colombia \\
\hline N. libradensis appressa & Campos, 1992 & Colombia \\
\hline N. lobulata & Campos, 1992 & Colombia \\
\hline N. macaranae & Campos, 1992 & Colombia \\
\hline N. perijaensis & Campos \& Lemaitre, 1998 & Colombia \\
\hline N. tencalanensis & Campos, 1992 & Colombia \\
\hline N. tonensis & Campos, 1992 & Colombia \\
\hline \multicolumn{3}{|l|}{ Pseudothelphusinae: Kingsleyini } \\
\hline Achagua & Campos, 2001 & \\
\hline A. casanarensis & Campos, 2001 & $\begin{array}{l}\text { Colombia } \\
\text { Continue }\end{array}$ \\
\hline
\end{tabular}


Table I. Continued.

\begin{tabular}{|c|c|c|}
\hline Taxon & Authority & Country \\
\hline Fredius & Pretzmann, 1967 & \\
\hline F. granulatus & Rodríguez \& Campos, 1998 & Colombia \\
\hline F. stenolobus & Rodríguez \& Suárez, $1994^{5}$ & Venezuela \\
\hline Kingsleya & Ortmann, 1897 & \\
\hline K. junki & Magalhães, 2003 & Brazil \\
\hline Microthelphusa & Pretzmann, 1968 & \\
\hline M. sucreensis & Rodríguez \& Campos, 2000 & Venezuela \\
\hline Odontothelphusa & Rodríguez, 1982 & \\
\hline O. lacandona & Álvarez \& Villalobos, 1998 & Mexico \\
\hline O. lacanjaensis & Álvarez \& Villalobos, 1998 & México \\
\hline O. palanquensis & Álvarez \& Villalobos, 1998 & Mexico \\
\hline O. toninae & Álvarez \& Villalobos, 1998 & Mexico \\
\hline \multicolumn{3}{|l|}{ Pseudothelphusinae: Potamocarcinini } \\
\hline Potamocarcinus & H. Milne-Edwards, 1853 & \\
\hline P. chajulensis & Álvarez \& Villalobos, 1998 & Mexico \\
\hline P. lobulatus & Campos \& Lemaitre, 2002 & Panamá \\
\hline P. pinzoni & Campos, 2003b & Colombia \\
\hline P. roatensis & Rodríguez \& López, 2003 & Honduras \\
\hline P. vulcanensis & Rodríguez, 2001 & El Salvador \\
\hline Phrygiopilus & Smalley, 1970 & \\
\hline P. montebelloensis & Álvarez \& Villalobos, $1998^{6}$ & México \\
\hline P. yoshibensis & Álvarez \& Villalobos, $1998^{6}$ & México \\
\hline Ptychophallus & Smalley, 1964 & \\
\hline P. barbillaensis & Rodríguez \& Hedström, 2000 & Costa Rica \\
\hline P. kuna & Campos \& Lemaitre, 1999 & Panama \\
\hline P. micracanthus & Rodríguez, 1994 & Costa Rica \\
\hline P. uncinatus & Campos \& Lemaitre, 1999 & Panama \\
\hline $\begin{array}{l}\text { Villalobosus, substitute for Stygothelphusa lopezformenti (Álvarez \& } \\
\text { Villalobos, 1991); type: S. lopezformenti (Álvarez \& Villalobos, 1991) }\end{array}$ & Ng \& Álvarez, 2000 & México \\
\hline Pseudothelphusa & De Saussure, 1857 & \\
\hline P. ayutlaensis & Álvarez \& Villalobos, 1997 & Mexico \\
\hline P. hoffmannae & Álvarez \& Villalobos, 1996 & Mexico \\
\hline P. nayaritae & Álvarez \& Villalobos, 1994 & Mexico \\
\hline Tehuana & Rodríguez \& Samalley, 1969 & \\
\hline T. chontalpaensis & Villalobos \& Álvarez, 2003 & Mexico \\
\hline T. jacatepecensis & Villalobos \& Álvarez, 2003 & Mexico \\
\hline T. lamothei & Álvarez \& Villalobos, 1994 & Mexico \\
\hline \multicolumn{3}{|l|}{ Pseudothelphusinae: Strengerianini } \\
\hline Chaceus & Pretzmann, 1965 & \\
\hline C.turikensis & Rodríguez \& Herrera, 1994 & Venezuela \\
\hline Phallangothelphusa & Pretzmann, 1965 & \\
\hline P. magdalenensis & Campos, 1998 & Colombia \\
\hline Strengeriana & Pretzmann, 1971 & \\
\hline S. cajaensis & Campos \& Rodríguez, 1993 & Colombia \\
\hline S. casallasi & Campos, 1999 & Colombia \\
\hline S. flagellata & Campos \& Rodríguez, 1993 & Colombia \\
\hline S. florenciae & Campos, 1995 & Colombia \\
\hline S. maniformis & Campos \& Rodríguez, 1993 & Colombia \\
\hline
\end{tabular}

${ }^{1}$ See also Capolongo \& Pretzmann (2002); ${ }^{2}$ See also Capolongo \& Pretzmann (2002); ${ }^{3}$ See also Campos (2003a); ${ }^{4}$ See also Rodrícuez et al. (2002); ${ }^{5}$ See also Rodrícuez \& Campos (1998); ${ }^{6}$ See also Rodrícuez (2001). 
1853, and one new Tehuana Rodríguez \& Smalley, 1969, were described from the state of Chiapas. In the genus Pseudothelphusa de Saussure, 1857 one species was described from the state of Nayarit and two from the state of Guerrero. With these additions the pseudothelphusid fauna of Mexico consists at present of 13 genera and 48 species (Tab. II), but there are many areas unexplored in southern Mexico, in the state of Chiapas, that may contain undescribed species (Álvarez \& VilLaLobos 1998). Of the additions made during this period one of the most interesting concerns the genus Phrygiopilus, previously restricted to Guatemala. With the two new species reported from Mexico the geographic range of the genus extends northward $335 \mathrm{~km}$.

Table II. Total number of genera and species of Pseudothelphusidae in several areas of the Neotropics up to 2004.

\begin{tabular}{lcc}
\hline Geographical areas & Genera & Species \\
\hline México & 13 & 48 \\
Central America & 13 & 43 \\
Antilles & 2 & 12 \\
Venezuela & 10 & 32 \\
Atlantic Guianas & 3 & 5 \\
Colombia & 13 & 82 \\
Ecuador & 3 & 19 \\
Peru & 4 & 7 \\
Brazil & 5 & 12 \\
\hline
\end{tabular}

Central America. Eight new species have been added to those known from Central America (CAmpos \& Lemaitre 1999, 2002, Rodríguez 2001, Rodríguez \& Hedström 2000, Rodríguez \& López 2003), including three new species of Potamocarcinus from Panamá, El Salvador, and the Roatan Island off Honduras, and five new species of the endemic Central American genus Ptychophallus Smalley, 1964, from Panamá and Costa Rica. CAMpos \& Lemaitre (1999) reviewed the taxonomic status of other species and theorizations about the role of the morphology and evolution of the structure of the first gonopod in different species were made by Rodríguez \& Hedström (2000).

Antilles. Rodríguez \& Williams (1995) described a new species of the West Indian genus Epilobocera Stimpson, 1860, E. wheterbeei, from Hispaniola characterized by its very small size. At the same time they presented SEM illustrations of the gonopods of three other of then known species.

The papers by Pretzmann (2000) and Capolongo \& PretzMann $(2000,2002)$ deserve special attention, because they made considerable alterations to the taxonomy of the genus Epilobocera, and their results were reported in a publication of very restricted diffusion, AGEMUS Nachrichten, the "organ of internal information of the working group on Evolution, $\mathrm{Hu}$ man Destiny and Meaningfulness ("Arbeits-Gemeinschaft Evolution Menschheitszukunft und Sinnfragen")".
Former authors distinguished four species in Cuba: (a) Epilobocera armata Smith, 1870, with the upper border of the front forming a strong tuberculated crest (RATHBUN 1905, BотT 1968, Chace \& Hobbs 1969, Rodríguez 1982). According to available records, the species is restricted to the eastern end of the island. The type locality is probably Baracoa, Provincia de Oriente, and other records are from the vicinities of this city (Rathbun 1905, Chace \& Hobbs 1969, Rodríguez 1982), with the exception of a record from Guantánamo, $80 \mathrm{~km}$ SE of Baracoa (RATHbun 1905). (b) Epilobocera cubensis Stimpson, 1860, with the front curving downwards very gradually (RATHBUN 1905, Chace \& Hobbs 1969, Rodríguez 1982). The type locality is Rio Yateras, near Guantánamo, Provincia de Oriente, a basin conterminous to the area of E. armata. The species has been recorded westward, up to the neighborhood of Havana (RATHBUN 1905, Rodríguez 1982), and Provincia Pinar del Rio (San Diego de los Baños) (RATHbun 1905). (c) Epilobocera gilmani (Smith, 1870), with the front curving downwards very gradually as in E. cubensis, but distinguished from this last by the shape of the third maxilliped (Rodríguez 1982). BотT (1968) gave this form a subspecific rank as Epilobocera cubensis gilmani. The type locality is in the Isla de Pinos (Isla de la Juventud) and according to the authors mentioned above, it is restricted to this island. (d) Epilobocera gertraudae Pretzmann, 1965, a species clearly differentiated from the other Cuban species by its pronounced stygobiont traits and only previously known from its type locality, Los Baños, Provincia Pinar del Rio [Cueva El Toro].

We have examined the material of Epilobocera gertraudae in the reference collection of the Instituto Venezolano de Investigaciones Científicas (IVIC), as follows: Cueva superior Majagua, Sierra de San Carlos, Provincia Pinar del Rio, Cuba, 2.VIII.1977, leg. O. Gómez, 1 male, carapace length $31.5 \mathrm{~mm}$, carapace breath $49.3 \mathrm{~mm}$.

According to the taxonomic arrangement proposed by Pretzmann (2000) and Capolongo \& Pretzmann (2000, 2002), the distribution of the species of Epilobocera in the Island of Cuba would be as follows:

a) Epilobocera cubensis cubensis. CAPOLOngo \& Pretzmann (2002) included under this species Epilobocera armata Smith, 1870, as a junior synonym. In the diagnosis, the front of the species is stated as acute, clearly advanced ("Stirn scharf, deutlich vorspringend"), and in the description the upper border is said to be weakly granulated, a little dentate ("Stirnrand ist schwach granuliert, wening eingedellt"). Finally, in the discussion of the distribution of species, the authors stated that all populations of E. cubensis are characterized by an acute advanced upper margin of front ("Alle diese Tiere sind durch eine scharfen vorspringenden oberen Stirnrand gekennzichnet"). CAPOLONGO \& PretzManN (2002) reported the typical Epilobocera cubensis cubensis from La Maya [25 km NE of Santiago, approximately], and Epilobocera cubensis najasensis, a subspecies of this (by inference), from the type locality Najasa [Sierra de Najasa, S of Cama- 
guey, Provincia de Camaguey]. The typical form is fragmented into Epilobocera cubensis cubensis Natio baracoensis [type locality: Baracoa, Provincia de Oriente] and additional paratypes from Paso de Cuba [10 km SSE of Baracoa]; Epilobocera cubensis cubensis Natio guisensis, type locality Río Guisa [draining into Cauto river, approximately $15 \mathrm{~km} \mathrm{NE}$ of Bayamo, Provincia de Oriente].

b) Epilobocera gilmani is said to comprise the typical form and two more subspecies. Epilobocera gilmani gilmani, in addition to the type locality in Isla de Pinos, is recorded from Cotorro [12 km W of Havana, Provincia de la Havana] and R. Jaimanitas [a locality not identified]. Epilobocera gilmani placensis, type locality Placetas $[32 \mathrm{~km}$ ENE of Santa Clara, Provincia de Villa Clara], and Epilobocera gilmani synoecia, type locality Cueva S. Tomas [Cueva San Tomás, Provincia de Pinar del Río], also inhabited by E. gertraudae. In their discussion of the distribution of species, CAPOLONGo \& PretzMann (2002: 4) used the name Epilobocera gilmani cuevanensis (nomina nuda) for a subspecies from Cueva S. Tomas. This is possibly a lapse for Epilobocera gilmani synoecia.

c) Epilobocera capolongoi a new species, whose type locality is Topo de Collantes, central Cuba [Topes de Collantes, at foot of Sierra de Trinidad, $50 \mathrm{~km} \mathrm{~S}$ of Santa Clara, Provincia de Villa Clara].This species has the upper border of front finely dentate and well marked, bent forward; the merus of the third maxilliped is rounded; the very wide exognath of third maxilliped (width/length $=0.5$ according to figure 1 of PreTZMANN 2000), distinguish this species from all other in the island.

d) Epilobocera (Neoepilobocera) gertraudae, restricted to the type locality (see above).

The classification postulated by Capolongo \& Pretzmann (2002) poses the following difficulties:

1) The synonymization of Epilobocera cubensis and E. armata is problematic. The illustrations of the first male gonopod of both species in CHAсе \& Hоввs (1969, figs 39a, b) shows substantial differences in the shape of the finger-like caudal process; furthermore, the number of strong spines on the bulging lateral process is 13 in E. armata and 8 in E. cubensis (for the significance of this last character, see Rodríguez \& Williams 1995).

2) Regarding the extension of the range of Epilobocera gilmani from Isla de Pinos to cover the western half of Cuba, it must be remarked that this species differs from $E$. cubensis only by a minor detail of the third maxilliped. Thus the descriptions given by CHACE \& HoBBs (1969) of both species are identical, except for the statements that in E. cubensis the "third maxilliped [has the]... distal margin [of merus] slightly concave", and in E. gilmani the "third maxilliped [has the]... distal margin [of merus] slightly regularly convex".

The diagnosis of this species by CAPOLOngo \& PretzManN (2002) is based mostly on negative characters and does not provide a firm ground for the separation of the species: Exognath of third maxilliped not expanded [to discriminate from Epilobocera capolongoi, but similar to the rest of species of the genus], legs not particularly slender [to discriminate from E. gertraudae, but similar to the rest of species of the genus], upper margin of front smooth, not projected [similar to $E$. cubensis]. Rodríguez (1982) has suggested that the two forms probably could be unified and E. gilmani considered a junior synonym of $E$. cubensis. However, before this action is taken, a careful examination of the first male gonopod of specimens from Isla de Pinos is advisable.

3) The extension of the geographical area and the division of a species of doubtful status, such as Epilobocera gilmani, into subspecies is inadvisable. A similar argument can be made for the split of Epilobocera cubensis, whose status regarding $E$. armata is insecure. The meaning of tetranomials such as Epilobocera cubensis cubensis Natio guisensis is not clear. Does 'Natio' refer to genetically differentiated populations or demes, or to the locality where the specimens were found? Due to the conflicting views regarding the status of the various populations in the islands of Cuba and Pinos, with the consequent nomenclatural confusion, it is possible that the only way to resolve this incertitude would be through a molecular genetics study.

Venezuela. Three new species have been added to the Venezuelan fauna during this period (Rodríguez \& Herrera 1994, Rodríguez \& Suárez 1994, Rodríguez \& Campos 2000). Fredius stenolobus Rodríguez \& Suárez, 1994 was described from the basin of the Rio Caura, a tributary of the Rio Orinoco. Chaceus turikensis Rodríguez \& Herrera, 1994 is a stygophile from a complex of caves in Mesa Turik, western Venezuela. Microthelphusa sucrensis Rodríguez \& Campos, 2000 presents an interesting case of teratology (RoDRíguez \& CAMPOS 2000). It was collected for the first time in 1930 in an inaccessible area at $1730 \mathrm{~m}$ altitude in eastern Venezuela, state of Sucre, and could not be identified due to the malformation of the first gonopod. A second collection in the same area at $1900 \mathrm{~m}$ altitude, in 1993, also produced male specimens with malformations in the first gonopod. Since malformations of the sexual appendages of Neotropical freshwater crabs are very rare, a genetical factor cannot be discarded.

With the addition of the taxa mentioned above, the total number of species and subspecies known from Venezuela increases to 32 (Table II). However, the morphology of the gonopod and the extension of the endognath of the third maxilliped in Eudaniela pestai (Pretzmann, 1965) led CAmpos (2001) to transfer it to her newly-erected genus Achagua. By this action the number of genera in Venezuela was elevated to ten.

Colombia. The intense faunistic work in Colombia by Campos $(1995,1998,1999,2000,2001,2003 a, b)$, Campos \& Lemaitre (1998), Campos \& Rodríguez $(1993,1995)$, Campos \& Valencia (2004), Campos et al. (2002), Rodríguez et al. (2002), and Rodríguez \& CAMpos (1998) has resulted in an important increase in the number of known species of pseudothelphusids in that country. According to M. Campos (personal communication) there are at present 82 species and subspecies (Table II). However there are still unexplored areas such as the isolated sierras to the east of the Andes, Serrania de San Lucas, Sierra de 
la Macarena, and Sierra de Chiribiquete. This last is geologically related to the Precambrian Guiana Shield and its geomorphology consists of tabletop mountains, similar to those of the Guianas (SÁnchez PÁEz et al. 1990). It may be guessed that the pseudothelphusid fauna of these sierras may consist either of Andean, Amazonian or Guianan species.

Brazil and the Atlantic Guianas. Magalhães \& RodrígueZ (2002) discussed the taxonomic and biogeographical status of Fredius reflexifrons (Ortmann, 1897) and Fredius fittkaui (Bott, 1967) and confirmed the validity of the former taxon. MAGALHÃES (2003), in his revision of the freshwater crabs of the Rio Xingú in the Amazon region, described the new species Kingsleya junki. The morphology of the first male gonopod in this species widely diverges from that of other four known species of the genus by the shape of the apical plate, with a rudimentary proximal lobe and an enlarged and serrated distal lobe. Another new species of this genus is being described from Rio Tocantins, in the southeastern Amazon basin (MAGalHães in press). Kingsleya sp. and K. siolii Bott, 1967 were considered as possible sister species that probably originated in the Tertiary period. With the addition of these species, 12 species divided among at least five genera, Brasiliothelphusa Magalhães \& Türkay, 1986, Fredius Pretzmann, 1967, Kingsleya Ortmann, 1897, Microthelphusa Pretzmann, 1968 and Prionothelphusa Rodríguez, 1980 are recognized from the Amazon region of Brazil.

No new taxa has been added to the three genera and 5 species known from Atlantic Guianas.

Ecuador. A revision of the known species in Ecuador, including the description of five new species, Hypolobocera esmeraldensis, H. konstanzae, H. muisnensis, H. mindonensis and Lindacatalina sumacensis, were provided by RoDríguez \& STERNBERG (1998). The validity of pentanomial names proposed in the literature for some Ecuadorian species was revised, the genera Hypolobocera Ortmann, 1897, Moritschus Pretzmann, 1965 and Lindacatalina Pretzmann, 1977 were redefined, and several species were reassigned among these genera. As it stands at present, the number of species known to occur within the Ecuadorian territory is 19 (Tab. II), divided among the three genera already mentioned.

Peru. Rodríguez \& Sú́rez (2004) reviewed six species of pseudothelphusid crabs from Peru. Among these, two new species of the genus Hypolobocera were described, bringing the number of pseudothelphusid species known to the country to seven.

\section{Species vectors for paragonimiasis}

Twenty two species of the more than 200 species of Pseudothelphusidae known has been cited as secondary hosts for Paragonimus (Tab. III). All these records were made before 1993, except those by Lamothe-Argumedo (1995) and Velez et al. (2003).

The species of Paragonimus involved are $P$. amazonicum Miyazaki, Grados \& Uyema, 1973, P. caliensis Little 1968, P. inca Miyazaki, Mazabel, Grados \& Uyema, 1975 and P. mexicanus Miyazaki \& Ishii, 1968. The records of Paragonimus westermani (Kerbert, 1878) from the Americas are incorrect and due to misidentifications owing to the assumption that this was the sole species of lung fluke (BLAIR et al. 1999). Areas of endemisms have been reported from Mexico, Central America, Colombia, Ecuador and Peru. The occurence in Venezuela was mentioned by TONONI (2004) based on reports of paragonimiasis cases from the state of Sucre. The parasites have not yet been reported in crabs from Brazil, although they are used as food by Indian populations in the country (C. Magalhães, unpublished data). Such a possibility still remains to be verified.

An interesting fact that can be derived from the knowledge available is that all the species of crabs involved are large (carapace breadth 5-10 cm) and inhabit areas below $300 \mathrm{~m}$ altitude. This fact can correlate with the location of human populations at these altitudes or the unedibility of the smaller crabs, rather than immunity of the crabs to the parasites. Research along these lines could be of great practical interest.

\section{Cavernicolous species}

Four species were recorded associated with caves since 1992, as follows: Epilobocera gilmani synoecia from Cueva San Tomas, Cuba, do not display adaptations to cave life in the eyes, color (which is described as darker than the typical subspecies), or other characters of carapace; only the legs are described as more slender particularly those of the fifth pair (CApolongo \& Pretzmann 2002). Chaceus turikensis from Cueva de Las Lianas, Venezuela, display as only obvious stygobiontic character the slenderness of the pereiopods, including the cheliped. The species is epigeous in localities where the daylight is considerably reduced (Rodríguez \& Herrera 1994). Phrygiopilus montebelloensis Álvarez \& Villalobos, 1998 from Gruta del Arco, and Phrygiopilus yoshibensis Álvarez \& Villalobos, 1998 from Sumidero Yoshib, both in the state of Chiapas, Mexico, come from subterranean waters, but Álvarez \& VILLALOBos (1998) stated that their presence there is accidental, since they have no troglobious adaptations. Effectively, Rodríguez (2001) recorded the first species from Laguna de Tizcaco, near the type locality, and the second in a stream $80 \mathrm{~km}$ from the type locality.

Probably only Chaceus turikensis could be considered as truly trogophile. If the other three species mentioned above are excluded, the number of cave pseudothelphusids would be 20 . However the difficulties mentioned in RoDRíGuEz (1992) regarding the discrimination of species from subterranean waters as stygobiont, stygophyle, or stygoxene must be taken into account.

\section{Anatomical adaptations}

The first male gonopods of Pseudothelphusidae display on their terminal portion a complex structure which usually consists of several processes. Each species possesses a distinctive morphology in these intromittant organs which differs from that of any other species within the family. Pretzmann (1973) showed that there are also species-associated differences in the openings of the females. A plausible hypothesis is that the corresponding differences in both male and female organs act as a mechanism of lock and key to prevent copulation between different species.

Revista Brasileira de Zoologia 22 (2): 354-365, junho 2005 
Table III. Species of Pseudothelphusidae crabs reported as hosts for lung flukes of the genus Paragonimus (Trematoda, Troglotrematidae) ${ }^{1}$.

\begin{tabular}{|c|c|c|}
\hline Host species & Country & Parasite \\
\hline Eudaniela garmani & Venezuela & P. mexicanus \\
\hline Hypolobocera aequatorialis & Ecuador & P. mexicanus \\
\hline H. gracilignatha & Peru & P. inca \\
\hline H. bouvieri monticola ${ }^{2}$ & Colombia & Paragonimus spp. \\
\hline H. chilensis & Peru & P. caliensis, P. amazonicum, P. mexicanus \\
\hline H. emberarum & Colombia & Paragonimus spp. \\
\hline Odontotelphusa maxillipes & México & P. mexicanus \\
\hline Potamocarcinus magnus & Costa Rica & P. caliensis, P. mexicanus \\
\hline Pseudothelphusa belliana & México & P. mexicanus \\
\hline P. dilatata & México, Costa Rica & P. mexicanus \\
\hline P. nayaritae ${ }^{3}$ & México & P. mexicanus \\
\hline P. propinqua & Guatemala & P. mexicanus \\
\hline P. terrestris ${ }^{3}$ & México & P. mexicanus \\
\hline Ptychophalus coclensis & Panama & P. mexicanus \\
\hline P. costaricensis & Costa Rica & P. mexicanus \\
\hline P. exilipes & Panamá & P. caliensis \\
\hline P. richmondi & Panama, Costa Rica & P. mexicanus \\
\hline P. tristani & Costa Rica & P. caliensis, P. mexicanus \\
\hline P. tumimanus & Costa Rica & P. mexicanus \\
\hline Raddaus bocourti & Guatemala & P. mexicanus \\
\hline R. tuberculatus & México & P. mexicanus \\
\hline Strengeria sp. & Colombia & P. caliensis \\
\hline
\end{tabular}

${ }^{1}$ For references to records before 1993 see Blair et al. (1999); ${ }^{2}$ Velez et al. (2003); ${ }^{3}$ Lamothe-Argumedo (1995).

Although presumably there is a weak selection pressure acting on the male organs (STERNBERg et al. 1999a), it has been observed that the progressive transformation of one type of gonopod into a slightly different one, forming the various species a continuous chorological series (Rodríguez 1986). Rodríguez \& HeAdsTöm (2000) observed this type of morphocline in the species of the genus Ptychophallus consisting in the progressive reaccommodation of the lateral lobe and the various components of the apex of the gonopod, to form a structure that possibly serves to receive and keep the spermatophore once it is extruded. This is fully developed in Ptychophallus goldmanni Pretzmann, 1965, but the other species can be arranged in a morphocline comprising several stages of development of this structure. If the hypothesis advanced above is correct, there must be a corresponding rearrangement of the female opening, in a sort of monospecific "coevolution", but Rodríguez \& HEAdstöM (2000) did not touch upon this aspect of the problem.

\section{Ecology}

Ecological studies about pseudothelphusid crabs are too few and sporadic. Teran et al. (1995), studying the food habits of river turtles in the Rio Guaporé, state of Rondonia, Brazil, showed that Podocnemis unifilis (Trochel, 1848) consumed pseudothel- phusid crabs, which occurred in $10.8 \%$ of the sampled stomaches. Maitland et al. (2002) reported the practical use of radio transmitters to track the amphibious freshwater land crab, Eudaniela garmani (Rathbun, 1898), in the rainforests of the Caribbean island of Tobago. In this same island, MaItLand (2003) also reported a very interesting case of predation on snakes by crabs of this species. In the southeastern part of the Brazilian Amazon, Port-Carvalho et al. (2004) recorded the predation of unindentified pseudothelphusid crabs by a population of the tufted capuchin monkey, Cebus apella (Linnaeus, 1758). More biological and ecological studies on representatives of this family are needed to better understand their role in the ecosystem.

\section{Biogeography}

Answering an argument by BãNÃRESCU (1990), who asserted that freshwater crabs are not a useful tool in biogeography, NG \& RoDríguez (1995) put forward several arguments in favor of the use of these organisms to falsify biogeographical hypotheses. In support of his assertion BãNÃRESCU (1990) maintained that freshwater crabs are able to cross salt-water barriers, or are derivatives of not too distant marine ancestors. Bãnãrescu's belief is based partially on the occurrence of pseudothelphusids in the Antilles and the mainland. Regarding this point, NG \& 
Rodríguez (1995) have pointed out that an alternative vicariant hypothesis has more factual support. A recent survey of insular species by Rodríguez \& López (2003) examined the case of the three species of the family found in Roatan Island (Honduras), Gorgona Island (Colombia), and the multiple distribution of the same species, Eudaniela garmani, in mainland Venezuela, Margarita Island and Trinidad, and Microthelphusa odaelkae (Bott, 1970) in Trinidad and Venezuela. In the case of the new species found in Roatan Island, Potamocarcinus roatensis Rodríguez \& López, 2003, a cladistic analysis shows that the sister species is Potamocarcinus magnus (Rathbun, 1896), a widespread species found throughout Central America. The vicariant disjunction of the two species is supported by paleographic data. A similar case occurs with Eudaniela garmani, but the geographical connection of the three disjunct areas up to late Quaternary possibly explain the lack of a vicariant speciation. The distribution of Microthelphusa odaelkae probably reflects an older connection with the continent. In the case of Hypolobocera gorgonensis von Prahl, 1983, found in mainland Ecuador and in Gorgona Island, the most probable explanation is rafting along the Humboldt Current.

BÃNÃRESCU's (1990) contention that freshwater crabs are derivatives of not too distant marine ancestors belong to a school of thought that assumes that freshwater crabs are a para- or polyphyletic assemblage, with each family (or even genera) originating from a nearby marine ancestor. A more recent hypothesis proposes the monophyly of all freshwater crab families, with sister group relationships for the Pseudothelphusidae + Gecarcinucoidea and the Potamoidea + Trichodactylidae (see NG \& RoDríGueZ 1995). These two schools of thought have been termed as the polyphyletic school and the archaic population school, respectively, by STERnBERg et al. (1999a). These authors, based on a cladistic analysis, proposes a third alternative hypothesis which states that "a widespread, predominantly littoral, marine urthoracotreme clade emerged during the Cretaceous", with a pancoastal distribution along the southern Thethys sea. This clade would have been monophyletic on the basis of 13 shared synapomorphies. This monophyletic group underwent an independent diversification in the freshwater or estuarine environments, whereas others diverged after entering freshwater.

Another result of STERnBERg et al. (1999a) cladistic study is that the Pseudothelphusidae appears as a basal group, with the rest of the thelphusids forming a sister clade, implying a more ancient differentiation of the family in relation to other freshwater crabs.

Two recent studies tend to elucidate the origin of the Kingsleyini. A cladistic analysis by STERnBERg et al. (1999b) has shown that the genus Eudaniela Pretzmann, 1971 is a paraphyletic group. Eudaniela pestai is positioned as the most basal taxon, not only in relation to Eudaniela, but within all kingsleyinian species compared in the analysis. This primitive condition is sustained by its underived first gonopod and longest third maxilliped exopod within the Kinsgleyini. Additionally, the discovery in the llanos of Colombia by CAMpos (2001) of a new species, Achagua casanarensis, closely related to Eudaniela pestai by these primitive traits, considerably extends the distribution of this basal group. However, being E. pestai (Pretzmann, 1965) the type species of the genus Eudaniela Pretzmann, 1971, the action of transfering E. pestai to the new genus Achagua, as proposed by CAMPos (2001), implied that Eudaniela and Achagua are synonyms, with Eudaniela taking priority over Achagua. A correcting action is in preparation (M.R. Campos, personal communication).

The prototypical Strengerianini-like gonopod and the partially enclosed efferent channel relates the basal group Achagua casanarensis/A. pestai to the Strengerianini. Data by G. Rodríguez \& H. Suárez (as yet unpublished) show that some undescribed species of the genus Microthelphusa from flattop mountains (tepuyes) in the Venezuela Guiana, display a gonopodal topology homologous to that of Achagua casanarensis. This anatomical confluence and the presence of small isolated tepuyes in the Colombian llanos point to the existence of an ancestral preAchagua population, derived from the ancient Strengerianini and widely distributed from the Colombian llanos, to the eastern Venezuelan and to the Venezuelan Guiana. A survey of the still unknown Colombian tepuyan pseudothelphusid fauna could be valuable to falsify this hypothesis.

Another interesting result of Sternberg et al. (1999b) is the positioning of Eudaniela garmani as basal taxon for Eudaniela sibling complex. Following the fragmentation of E. garmani range during Quaternary times (RoDRíguez \& López 2003), cladogenetic events would have proceeded in a westward direction along the Venezuelan coastal range. Combining the results of STERnberg et al. (1999b) with those of Rodríguez \& López (2003) it is apparent that the several vicariant events that led to the allopatric speciation of the Eudaniela sibling complex took place in quite recent geological time.

Several taxonomic studies have shed light on the areal distributions of the Pseudothelphusidae. Research by Álvarez \& Villalobos (1998) has evidenced a high diversification of pseudothelphusids in the Mexican state of Chiapas. Seven genera and thirteen species, representing three of the five tribes that compose the subfamily Pseudothelphusinae are found in Chiapas, and these authors anticipate that more new species will be found, since vast areas still remain unexplored. This number of taxa represents $27 \%$ of all the species found in the Mexican territory. This high biodiversity is in line with RoDRíGuEz' (1986) assertion that the neighboring areas east of the Isthmus of Tehuantepec are an area of maximum concentration of genera and species, where three distinct phyletic lines converge. The high speciation in this area is explained by this author by the marine transgressions that occurred during the Cenozoic that, although were not complete and did not produce disruptions of the land areas, conditions of aridity may have acted as temporary barriers and promoted repeated allopatric speciations. 
Another area of high diversity is found in Colombia (RodRíguez 1986) where the variety of topographical relief determines a multiplicity of environments favorable for allopatric speciation. However, this rich pseudothelphusid fauna is not biogeographically homogeneous. CAmpos et al. (2002) have found that the southern Andean pseudothelphusids of Colombia have affinities with the pseudothelphusid fauna of Ecuador, and points to a taxonomic compact of southern taxa that extends into southeastern Colombia and the Amazonian and Pacific slopes of Ecuador. This southern compact is separated by the water divides of the San Juan, Cauca and Magdalena basins from the northern species found at a short distance north of these divides.

The southern set of species mentioned comprises three distinct phyletic lines: (a) The species of the genus Hypolobocera with a lanceolate apex; (b) the genus Lindacatalina; and (c) the genus Moritschus. These three phyletic lines constitute the pseudothelphusid fauna of Ecuador (Rodríguez \& STERnberg 1998), and continues southward to Peru distributed in two distinct geographical areas, separated by the water divides of the Andean Cordillera. After a peak of biodiversity in the Ecuadorian Andes, a sharp decrease is observed in a southward direction (RoDRíguEz \& SuÁrez 2004). These authors quantified this decline computing the total number of species and the number of species that appeared for the first time at each degree of latitude from $6^{\circ} \mathrm{N}$ to $12^{\circ} \mathrm{S}$. In the southern Colombian Andes $\left(6^{\circ} \mathrm{N}\right.$ to $\left.2^{\circ} \mathrm{N}\right)$ the diversity of species is high, but it increases even further in Ecuador $\left(1^{\circ} \mathrm{N}\right.$ to $\left.5^{\circ} \mathrm{S}\right)$; there is a sharp decline in the Peruvian Andes and after $11^{\circ} \mathrm{S}$ no new species appear. Thus it is an impoverished pseudothelphusid fauna that reaches the southern limits of the family, and beyond $13^{\circ} \mathrm{S}$, no species of pseudothelphusid is found.

Three taxonomic groups of freshwater crabs are clearly delimited in the Amazon basin: (a) the Kingsleyini, restricted to the lower planes of the Amazon basin; (b) the Hypolobocerini, that do not descend beyond $400 \mathrm{~m}$ altitude; and (c) the species of the family Trychodactylidae which share a common territory throughout the basin with the Kingsleyini (RoDríguez \& Súfrez 2004). Each kingsleyinian species seems to have a territorial delimitation, as exemplified by the separation of Fredius reflexifrons and $F$. fittkaui which occupy discrete areas along the main axis of the Amazon River and in the upper Rio Negro basin, respectively, with a short overlap only in the Atlantic Guianas (Magalhães \& Rodríguez 2002). The water divides of Ucayali River form the southwestern Amazonian limit of the pseudothelphusids and no species are found in the neighboring southern basins (RodríguEz \& SuÁrez 2004). This group, however, extended its eastern limits beyond the Amazon basin, as Fredius reflexifrons was recently recorded in the Serra da Ibiapada region, in the state of Ceará, Northeastern Brazil (MagalHãEs et al. 2005). The kingsleyinian fauna of southern tributaries of the eastern Amazon Basin is still poorly known, but recent findings from Rio Xingu, Rio Tocantins and Rio Tapajós basins (MAGALHães
2003, in press, and unpublished data) indicate that this group may have had a quite complex evolutionary history within the Amazonian portion of the Brazilian Shield.

\section{ACKNOWLEDGMENTS}

We thank Prof. Martha R. Campos, from the Universidad Nacional de Colombia, for unpublished data on Colombian pseudothelphusid crabs, and Mr. George Nakamura, for reviewing the English text. The junior author (CM) is thankful to Conselho Nacional de Desenvolvimento Científico e Tecnológico - CNPq for an ongoing research grant.

\section{REFERENCES}

Acha, P.N. \& B. SZyFres. 2001. Zoonosis y enfermedades transmisibles communes al hombre y a los animales. Washington, D.C., Panamerican Health Organization, XVIII+398p.

Álvarez, F. \& J.L. Villalobos. 1994. Two new species and one new combination of freshwater crabs from Mexico (Crustacea: Brachyura: Pseudothelphusidae). Proceedings of the Biological Society of Washington, Lawrence, 107 (4): 729-737.

Álvarez, F. \& J.L. Villalobos, J.L. 1996. Especie nueva de cangrejo de agua dulce del género Pseudothelphusa (Brachyura: Pseudothelphusidae) de Guerrero, México. Anales del Instituto de Biología de la Universidad Nacional Autónoma de México, Zoología, México, 67 (2): 297-302.

Álvarez, F. \& J.L. Villalobos, J.L. 1997. Pseudothelphusa ayutlaensis, a new species of freshwater crab (Crustacea: Brachyura: Pseudothelphusidae) from Mexico. Proceedings of the Biological Society of Washington, Lawrence, 110 (3): 388393.

Álvarez, F. \& J.L. Villalobos. 1998. Six new species of fresh-water crabs (Brachyura: Pseudothelphusidae) from Chiapas, Mexico. Journal of Crustacean Biology, Lawrence, 18 (1): 187-198.

BÃNÃRESCU, P. 1990. Zoogeography of freshwaters. 1. General distribution and dispersal of freshwater animals. Wiesbaden, AULA-Verlag, 511p.

Blair, D.; Z-B Xu \& T. Agatsuna. 1999. Paragonimiasis and the genus Paragonimus. Advances in Parasitology, London, 42: 113-222.

Вотт, R. 1968. Flub-Krabben aus dem ostlichen Mittel-Amerika und von den Größen Antillen. (Crustacea, Decapoda). Senckenbergiana biologica, Frankfurt a.M., 49: 39-49.

Campos, M.R. 1992. New species of fresh-water crabs of the genus Neostrengeria (Crustacea: Decapoda: Pseudothelphusidae) from Colombia. Proceedings of the Biological Society of Washington, Lawrence, 105 (3): 540-554.

Campos, M.R. 1995. A new species of freshwater crab of the genus Strengeriana from Colombia (Crustacea: Decapoda: Pseudothelphusidae). Proceedings of the Biological Society of Washington, Lawrence, 108 (1): 98-101. 
Campos, M.R. 1998. A new species of freshwater crab of the genus Phallangothelphusa Pretzmann, 1965 from Colombia (Crustacea: Decapoda: Pseudothelphusidae). Proceedings of the Biological Society of Washington, Lawrence, 111 (1): 92-96.

Campos, M.R. 1999. A new species of freshwater crab of the genus Strengeriana Pretzmann, 1971, from Colombia (Crustacea: Decapoda: Pseudothelphusidae). Proceedings of the Biological Society of Washington, Lawrence, 112 (2): 405-409.

CAmpos, M.R. 2000. Neostrengeria binderi, a new species of pseudothelphusid crab from the eastern Andes of Colombia (Crustacea: Decapoda: Brachyura). Proceedings of the Biological Society of Washington, Lawrence, 113 (2): 401405.

Campos, M.R. 2001. A new genus and species of freshwater crab from Colombia (Crustacea: Decapoda: Pseudothelphusidae). Proceedings of the Biological Society of Washington, Lawrence, 114 (4): 938-943.

Campos, M.R. 2003a. A review of the freshwater crabs of the genus Hypolobocera Ortmann, 1897 (Crustacea: Decapoda: Brachyura: Pseudothelphusidae), from Colombia. Proceedings of the Biological Society of Washington, Lawrence, 116 (3): 754-802.

CAmpos, M.R. 2003b. A new species of freshwater crab of the genus Potamocarcinus H. Milne-Edwards, 1853 (Crustacea: Brachyura: Pseudothelphusidae) from Colombia. Revista de la Academia Colombiana de Ciencias Exactas, Físicas y Naturales, Bogotá, 27 (103): 283-286.

Campos, M.R. \& R. Lemaitre. 1998. A new freshwater crab of the genus Neostrengeria Pretzmann, 1965, from Colombia (Crustacea: Decapoda: Brachyura: Pseudothelphusidae), with a key to the species of the genus. Proceedings of the Biological Society of Washington, Lawrence, 111 (4): 899-907.

Campos, M.R. \& R. Lemaitre. 1999. Two new freshwater crabs of the genus Ptychophallus Smalley, 1964 (Crustacea: Decapoda: Brachyura: Pseudothelphusidae) from Panamá, with notes on the distribution of the genus. Proceedings of the Biological Society of Washington, Lawrence, 112 (3): 553561.

Campos, M.R. \& R. Lemaitre. 2002. A new species of freshwater crab of the genus Potamocarcinus H. Milne-Edwards, 1853 (Crustacea: Decapoda: Brachyura: Pseudothelphusidae) from Panamá. Proceedings of the Biological Society of Washington, Lawrence, 115 (3): 600-604.

Campos, M.R. \& G. Rodríguez. 1993. Three new species of Strengeriana from Colombia (Crustacea: Decapoda: Pseudothelphusidae). Proceedings of the Biological Society of Washington, Lawrence, 106 (3): 508-513.

Campos, M.R. \& G. Rodríguez. 1995. Two new species of freshwater crabs of the genus Hypolobocera from Colombia (Crustacea: Decapoda: Pseudothelphusidae). Proceedings of the Biological Society of Washington, Lawrence, 108 (4): 649655.
Campos, M.R. \& D.M. Valencia. 2004. Two new species of freshwater crabs of the genus Chaceus Pretzmann, 1965 from the Serranía de Perijá of Colombia (Crustacea: Decapoda: Pseudothelphusidae). Proceedings of the Biological Society of Washington, Lawrence, 117 (1): 35-41.

Campos, M.R.; C. Magalhães \& G. Rodríguez. 2002. The freshwater crabs of southern Colombia and their biogeographical affinities (Brachyura: Pseudothelphusidae). Nauplius, Botucatu, 10 (1): 15-25.

Capolongo, D. \& G. Pretzmann. 2000. Die Bedeutung der Süßwasserkrabben Cubas für die Evolutiontheorie. AGEMUS Nachrichten, Wien, (61b): 3.

Capolongo, D. \& G. Pretzmann. 2002. Süßwasserkrabben von Cuba. AGEMUS Nachrichten, Wien, (67b): 1-4.

Chace, F. \& H.H. Hobbs. 1969. The freshwater and terrestrial Decapod Crustaceans of the West Indies with special reference to Dominica. Bulletin of the United States National Museum, Washington, D.C., 292: 1-258.

Lamothe-Argumedo, R. 1995. Sobre dos hospederos nuevos de Paragonimus mexicanus en México. Anales del Instituto de Biología de la Universidad Autónoma de México, Zoología, México, 66: 147-150.

Magalhães, C. 2003. The occurrence of freshwater crabs (Crustacea: Decapoda: Pseudothelphusidae, Trichodactylidae) in the Rio Xingu, Amazon Region, Brazil, with description of a new species of Pseudothelphusidae. Amazoniana, Kiel, 17 (3-4): 377-386.

Magalhães, C. (in press). A new species of Pseudothelphusidae crab (Crustacea: Decapoda) from the southeastern Amazon Basin. Nauplius, Botucatu, 12 (2).

Magalhães, C. \& G. Rodríguez. 2002. The systematic and biogeographical status of Fredius reflexifrons (Ortmann, 1897) and F. fittkaui (Bott, 1967) (Crustacea: Brachyura) from the Amazon and Atlantic Guianas river basins. Acta Amazonica, Manaus, 32 (4): 677-689.

Magalhães, C; F.A. Abrunhosa; M.O. Pereira \& M.A. Melo. 2005. New records of Fredius denticulatus (H. Milne-Edwards, 1853) and F. reflexifrons (Ortmann, 1897), and the eastern limits of the distribution of pseudothelphusid crabs (Crustacea: Decapoda) in Brazil. Acta Amazonica, Manaus, 35 (1): 9396.

Maitland, D.P. 2003. Predation on snakes by the freshwater land crab Eudaniela garmani. Journal of Crustacean Biology, Lawrence, 23 (1): 241-246.

Maitland, D.P.; R.L. Jackson; R.J. Ladle \& P. Ward. 2002. Field considerations and problems associated with radio tracking a tropical fresh-water land crab. Journal of Crustacean Biology, Lawrance, 22 (2): 493-496.

Milne-Edwards, H. 1853. Mémoire sur la famille des Ocypodiens. Annales des Sciences Naturelles, Paris, (3) 20: 163-226.

NG, P.K.L. \& F. Álvarez. 2000. Villalobosus, a replacement name for Stygothelphusa Álvarez and Villalobos, 1991 (Crustacea: Brachyura: Pseudothelphusidae), preoccupied by Stygothel- 
phusa Ng, 1989 (Crustacea: Brachyura: Gecarcinucidae). The Raffles Bulletin of Zoology, Singapore, 48 (2): 337.

NG, P.K.L. \& G. Rodríguez. 1995. Freshwater crabs as poor zoogeographical indicators: a critique of Bãnãrescu (1990). Crustaceana, Leiden, 68: 636-645.

Port-Carvalho, M.; S.F. Ferrari \& C. Magalhães. 2004. Predation of crabs by tufted capuchins (Cebus apella) in eastern Amazonia. Folia Primatologica, Basel, 75 (3): 154-156.

Pretzmann, G. 1973. Grundlagen und Ergebnisse der Systematik des Pseudothelphusidae Zeitschrift für zoologische Systematik und Evolutionsforschung, Hamburg/Berlin, 11 (3): 196-218.

Pretzmann, G. 2000. Eine neue Subwasserkrabbe aus Cuba. AGEMUS Nachrichten, Wien, (61b): 1-3.

Rathbun, M.J. 1905. Les crabes d'eau douce (Potamonidae). Nouvelles Archives du Muséum d'Histoire Naturelle, Paris, (4) 7: 159-321.

Rodríguez, G. 1982. Les crabes d'eau douce d'Amerique. Famille des Pseudothelphusidae. Paris, ORSTOM, Faune Tropicale 22, 224p.

Rodríguez, G. 1986. Centers of Distribution of Neotropical Freshwater Crabs, p. 51-67. In: R.H. Gore \& K.L. Heck (Eds). Biogeography of the Crustacea. Rotterdam, A.A. Balkema, Crustacean Issues 4, 292p.

Rodríguez, G. 1992. The freshwater crabs of America. Family Trichodactylidae and supplement to the family Pseudothelphusidae. Paris, ORSTOM, Faune Tropicale 31, 189p.

Rodríguez, G. 1994. A revision of the type material of some species of Hypolobocera and Ptychophallus (Crustacea: Decapoda: Pseudothelphusidae) in the National Museum of Natural History, Washington, D.C., with descriptions of a new species and a new subspecies. Proceedings of the Biological Society of Washington, Lawrence, 107 (2): 296307.

Rodríguez, G. 2001. New species and records of pseudothelphusid crabs (Crustacea: Brachyura) from Central America in the Museum of Natural History of Tulane University. Proceedings of the Biological Society of Washington, Lawrence, 114 (2): 435-443.

Rodríguez, G. \& M.R. Campos. 1998. A cladistic revision of the genus Fredius (Crustacea: Decapoda: Pseudothelphusidae) and its significance to the biogeography of the Guianan lowlands of South America. Journal of Natural History, London, 32: 763-775.

Rodríguez, G. \& M.R. Campos. 2000. Microthelphusa sucreensis, a new species of Pseudothelphusidae (Decapoda), with notes on abnormalities in the sexual appendages of fresh-water crabs. Journal of Crustacean Biology, Lawrence, 20 (special number 2): 332-336.

Rodríguez, G. \& I. Hedström. 2000. The freshwater crabs of the Barbilla National Park, Costa Rica (Crustacea: Brachyura: Pseudothelphusidae), with notes on the evolution of structures for spermatophore retention. Proceedings of the
Biological Society of Washington, Lawrence, 113 (2): 420425.

Rodríguez, G. \& F. Herrera. 1994. A new troglophilic crab, Chaceus turikensis, from Venezuela, and additional notes on the stygobiont crab Chaceus caecus Rodríguez and Bosque, 1990 (Decapoda: Brachyura: Pseudothelphusidae). Mémoires de Biospéologie, Moulis-Saint Girons, 21: 121-126.

Rodríguez, G. \& B. López. 2003. Insular species of Neotropical freshwater crabs (Crustacea: Brachyura). Journal of Natural History, London, 37 (21): 2599-2614.

Rodríguez, G. \& A.E. Smalley. 1969. Los cangrejos de agua dulce de México de la familia Pseudothelphusidae (Crustacea: Brachyura). Anales del Instituto de Biología de la Universidad Nacional Autónoma de México, Zoologia, México, 40: 69-112.

Rodríguez, G. \& R. von Sternberg. 1998. A revision of the freshwater crabs of the family Pseudothelphusidae (Decapoda: Brachyura) from Ecuador. Proceedings of the Biological Society of Washington, Lawrence, 111 (1): 110-139.

Rodríguez, G. \& H. Suárez. 1994. Fredius stenolobus, a new species of freshwater crab (Decapoda: Brachyura: Pseudothelphusidae) from the Venezuelan Guiana. Proceedings of the Biological Society of Washington, Lawrence, 107 (1): 132136.

Rodríguez, G. \& H. SuÁrez. 2004. The southern limits of the freshwater crabs of the family Pseudothelphusidae (Decapoda: Brachyura) with a revision of the species from Peru. Amazoniana, Kiel, 18 (1-2): 11-28.

Rodríguez, G. \& A.B. Williams. 1995. Epilobocera wetherbeei, a new species of freshwater crab (Decapoda: Brachyura: Pseudothelphusidae) from Hispaniola. Proceedings of the Biological Society of Washington, Lawrence, 108 (1): 76-83.

Rodríguez, G.; M.R. Campos \& B. López. 2002. New species and new records of pseudothelphusid crabs (Crustacea: Brachyura) from Colombia. Tulane Studies in Zoology and Botany, New Orleans, 31 (2): 1-17.

Sánchez Páez, H., J.I. Hernández Camacho; J.V. Rodríguez Mahecha \& C. Castaño Uribe. 1990. Nuevos Parques Nacionales de Colombia. Bogota, Inderena, 240p.

Smalley, A.E. 1964. The river crabs of Costa Rica, and the subfamilies of the Pseudothelphusidae. Tulane Studies in Zoology, New Orleans, 12 (1): 5-13.

SAussure, H. DE. 1857. Diagnoses de quelques crustacés nouveaux des Antilles et du Mexique. Revue et Magasin de Zoologie Pure et Appliquée, Paris, (2) 9: 304-306.

Sternberg, R. von; N. Cumberlidge \& G. Rodríguez. 1999a. On the marine sister groups of freshwater crabs. Journal of Zoological Systematics and Evolutionary Research, Berlin, 37: 19-38.

Sternberg, R. von; L.A. Galindo \& E.M. Gonzalez. 1999b. Cladistic analysis of the Eudaniela complex (Crustacea: Decapoda: Pseudothelphusidae). Hydrobiologia, Den Haag, 416: 139147. 
Stimpson, W. 1860. Notes on North American Crustacea, in the Museum of the Smithsonian Institution. No. 11. Annals of the Lyceum of Natural History of New York, New York, 7: 177-246.

Teran, A.F.; R.C. Vogt \& M.F.S. Gomez. 1995. Food habits of an assemblage of five species of turtles in the Rio Guapore, Rondonia, Brazil. Journal of Herpetology, Athens, 29 (4): 536-547.

Tononi, T. DE 2004. Diseñan método para diagnosticar la paragonimiasis en Venezuela. Oriente Universitario, Cuma- ná, (176): 18.

Velez, I.; L.E. Velasquez \& I.D. Velez. 2003. Morphological description and life cycle of Paragonimus sp. (Trematoda: Troglotrematidae): Causal agent of human paragonimiasis in Colombia. The Journal of parasitology, Lawrence, 89: 749-755.

Villalobos, J.L. \& F. Álvarez. 2003. Two new species of freshwater crabs of the genus Tehuana (Brachyura: Pseudothelphusidae) from southern Mexico. Journal of Crustacean Biology, Lawrence, 23 (1): 223-229.

Received in 05.VIII.2004; accepted in 12.V.2005. 